\title{
Nodulation Study and Characterization of Rhizobial Microsymbionts of Forage and Pasture Legumes in South Africa
}

\author{
Ahmed Idris Hassen ${ }^{1, *}$, Francina Lebogang Bopape ${ }^{1}$, Marike Trytsman ${ }^{2}$ \\ ${ }^{1}$ Agricultural Research Council - Plant Protection Research Institute Private bag X134, Queenwood, Pretoria, South Africa \\ ${ }^{2}$ ARC-Animal Production Institute, Private bag X05, Lynn East, South Africa \\ *Corresponding author: HassenA@arc.agric.za
}

Received March 28, 2014; Revised April 08, 2014; Accepted April 25, 2014

\begin{abstract}
Bacterial strains formerly isolated from the root nodules of indigenous and exotic forage legumes and preserved at the South African Rhizobium Culture Collection (SARCC) were tested for nodulation of their original host. The nodulation authentication trial was conducted following the Koch's postulate experiment under glasshouse condition and revealed that all bacterial strains are root nodule micro-symbionts of the forage legumes from which they were initially isolated. Nodulation and improved growth of the legumes was achieved by the tested strains with statistically significant $(p=0.05)$ increase in plant biomass and nodule number in comparison with the un-inoculated controls. To elucidate their identity and phylogenetic relatedness, the effective strains were selected and characterized by means of the $16 \mathrm{~S}$ ribosomal RNA sequence analysis. The analysis confirmed that the isolates nodulating Macrotyloma axillare, Desmodium uncinatum, Indigofera spicata var. spicata and Stylosanthus gracillis predominantly belong to the genus Bradyrhizobium. Vigna unguiculata and Vigna sp. were nodulated by strains belonging to members of the genus Bradyrhizobium, Sinorhizobium and Rhizobium. The results obtained in this study provide baseline information in the investigation of the legume-rhizobium interaction on South African soils, and are also of paramount importance in the selection and development of commercial rhizobium inoculants for sustainable production of forage and other essential legumes.
\end{abstract}

Keywords: nodulation, Rhizobium, Bradyrhizobium sp. $16 \mathrm{~S}$ rRNA, Forage legumes, Cross inoculation group

Cite This Article: Ahmed Idris Hassen, Francina Lebogang Bopape, and Marike Trytsman, "Nodulation Study and Characterization of Rhizobial Microsymbionts of Forage and Pasture Legumes in South Africa." World Journal of Agricultural Research, vol. 2, no. 3 (2014): 93-100. doi: 10.12691/wjar-2-3-2.

\section{Introduction}

The nitrogen fixing symbiosis of legumes with rhizobia is one of the most important plant microbe interactions which play an essential role in the nitrogen cycle, especially in the tropics $[4,20]$. The symbiosis enormously promotes the protein content of legumes which is vital in improving the diets of many resource poor communities who mainly depend on leguminous crops as their important source of protein. Biological nitrogen fixation resulting from the legume-rhizobium symbiotic interaction is not only confined to fixing nitrogen and improving the protein content of legume crops which are used for human consumption. Forage and pasture legumes improve the nitrogen $(\mathrm{N})$ status of soils thereby increasing soil fertility and can also be used in rotation systems and to help control pests, diseases and weeds [12,23]. Nitrogen fixing forage legumes have also an important role in animal production and ruminant productivity [24]. In terms of $\mathrm{N}_{2}$ fixation efficiency, there are evidences that perennial forage legumes (e.g. Trifolium repens L., Trifolium pretense, Medicago sativa, L. and Lotus corniculatus) are usually more effective in deriving higher percentage of nitrogen from the atmosphere $\left(\mathrm{N}_{2}\right)$ than most grain legume species [18].

Like many other grain legumes, forage and pasture legumes form symbiotic associations with a group of bacteria, generally termed as rhizobia. With the advancement of bacterial phylogenetics based on the sequences of the conserved small subunit of $16 \mathrm{~S}$ ribosomal RNA [38,39], the taxonomy of rhizobia is rapidly changing. Currently the group is divided into six main genera including Rhizobium, Bradyrhizobium, Mesorhizobium, Sinorhizobium Azorhizobium and a recently described genus Allorhizobium [3,8,15]. However, it is not only the taxonomy of rhizobia which is changing from time to time. The selection of appropriate rhizobial microsymbionts is becoming a complex procedure due to the fact that several legumes species can be nodulated by single rhizobia [9]. Yet, the symbiotic association between the legumes and their microbial symbionts play a significant role in agriculture worldwide by reducing ca. 100 million metric tons of atmospheric nitrogen saving US\$ 8 billion/year on fertilizer N [1,10].

The South African Rhizobium Culture Collection (SARCC) hosts a large collection of rhizobial strains 
isolated from the root nodules of various indigenous and exotic legumes and those obtained from various sources in the past. These Rhizobia are preserved both as frozen and freeze dried cultures and are routinely monitored and tested for their purity, viability and their nodulation efficiency under glasshouse and field conditions. Earlier strain selection studies done on indigenous legumes of South Africa resulted in the development of commercial rhizobial inoculants which are currently available on local markets $[2,30]$. However, most of the strains developed into commercial inoculants are associated with the root nodules of legumes which are mainly used for human consumptions. Moreover, due to the very little attention given to forage and pasture legumes, information on the symbiotic interaction and identity of rhizobia associated with forage and pasture legumes is scarce in South Africa. The main objective of the current study is therefore to screen and characterize rhizobial strains that are able to nodulate and fix nitrogen in selected indigenous and exotic forage legumes commonly used in South Africa.

\section{Materials and Methods}

\subsection{Rhizobial Strains}

Table 1. List of strains of rhizobia used in the glasshouse Koch's postulate experiment for nodulation of selected indigenous and exotic forage legumes and similarities of the 16S ribosomal RNA sequences of the isolates with that of reference strains from GenBank

\begin{tabular}{|c|c|c|c|c|c|}
\hline \multirow{2}{*}{$\begin{array}{c}\text { Rhizobia SARCC }^{1} \text { Strains } \\
\text { strain code } \\
\text { XBQ5 SARCC-401 }\end{array}$} & \multirow{2}{*}{$\frac{\text { Original host }}{\text { Desmodium uncinatum }}$} & Glasshouse test ${ }^{2}\left(\operatorname{Nod}^{+/}\right)$ & \multicolumn{2}{|c|}{$\begin{array}{c}\text { 16S rRNA sequence BLAST } \\
\text { search }^{3}\end{array}$} & \multirow[t]{2}{*}{$\begin{array}{c}\% \\
\text { similarity } \\
\end{array}$} \\
\hline & & D. uncinatum $(+)$ & $\begin{array}{l}\text { Bradyrhizobium elkanii } \\
\text { CCBAU53142 }\end{array}$ & $99 \%$ & \\
\hline XBD2 SARCC-388 & $\begin{array}{l}\text { Cyamopsis } \\
\text { tetragonoloba }\end{array}$ & Vigna unguiculata $(+)$ & B. japonicum SEMIA 6439 & $99 \%$ & \\
\hline XHF1 SARCC-465 & Vigna unguiculata & Vigna unguiculata $(+)$ & $\begin{array}{l}\text { Sinorhizobium meliloti } \\
\text { CCNWX0515 }\end{array}$ & $98 \%$ & \\
\hline XHF3 SARCC-470 & Vigna unguiculata & $\begin{array}{l}\text { Vigna unguiculata }(+) \\
\text { Vigna unguiculata }(+)\end{array}$ & B. japonicum strain $\mathrm{H} 1$ & $99 \%$ & \\
\hline XHF12 SARCC-467 & Vigna unguiculata & $\begin{array}{c}\text { Stylosanthus gracillis } \\
(+)\end{array}$ & B. japonicum CCBAU53152 & $99 \%$ & \\
\hline XHF14 SARCC-469 & Vigna unguiculata & Vigna sp. (+) & $\begin{array}{l}\text { Bradyrhizobium sp. CCBAU } \\
2303\end{array}$ & $99 \%$ & \\
\hline XHH1 SARCC-508 & & Vigna sp. $(+)$ & Rhizobium sp. UMR 7363 & $97 \%$ & \\
\hline XBU3 SARCC-404 & Dolichos axillaries & $\begin{array}{c}\text { Macrotyloma axillare } \\
(+)\end{array}$ & B. japonicum NA110 & $99 \%$ & \\
\hline XBU4 SARCC-405 & Dolichos formosus & $\underset{(+)}{\text { Macrotyloma axillare }}$ & B. elkani CCBAU 33018 & $91 \%$ & \\
\hline XBV7 SARCC408 & Dolichos lablab & $\underset{(+)}{\text { Macrotyloma axillare }}$ & B. yaunmingense $\mathrm{MN}-\mathrm{S}$ & $98 \%$ & \\
\hline XHG1 SARCC504 & Stylosanthus gracilis & $\begin{array}{c}\text { Stylosanthus gracilis } \\
(+)\end{array}$ & Bradyrhizobium sp IV-123 & $98 \%$ & \\
\hline XGA1 SARCC483 & $\begin{array}{l}\text { Desmodium } \\
\text { nacaraguence }\end{array}$ & $\begin{array}{l}\text { Desmodium } \\
\text { uncinatum }(+)\end{array}$ & B. elkanii USDA 4348 & $99 \%$ & \\
\hline XGE1 SARCC-488 & Indigofera hirsuta & Indigofera spicata $(+)$ & B. elkanii USDA 4348 & $91 \%$ & \\
\hline XCG2 SARCC-412 & Indigofera hirsuta & Indigofera spicata (+) & B. japonicum CCBAU 53142 & $99 \%$ & \\
\hline XGO1 SARCC-495 & Indigofera hirsuta & Indigofera spicata (+) & B. elkanii USDA 4348 & $98 \%$ & \\
\hline SA59-2c SARCC-597 & Indigofera hirsuta & Indigofera spicata $(+)$ & Bradyrhizobium sp. UFLO4 & $99 \%$ & \\
\hline SA59-2e SARCC-599 & Indigofera hirsuta & Indigofera spicata $(+)$ & Bradyrhizobium sp. SEMIA 929 & $99 \%$ & \\
\hline SA59-2f SARCC-600 & Indigofera hirsuta & Indigofera spicata $(+)$ & B. japonicum SEMIA 6002 & $99 \%$ & \\
\hline
\end{tabular}
${ }^{1}$ SARCC = South African Rhizobium Culture Collection.

${ }^{2}$ The glasshouse Koch's postulate was tested on these legumes. $(+)=$ nodulation, $(-)$ absence of nodules

${ }^{3}$ The 16S ribosomal RNA sequences of all the rhizobium strains used in this study were compared with available sequences in the NCBI data bases to establish their phylogenetic relationships.

Seeds were surface sterilized using the protocol described for legume seeds [29]. Briefly the seeds were first immersed in 3\% sodium hypochlorite solution for 3 min. The excess bleach is drained off before the seeds were rinsed with five changes of sterile distilled water and imbibed by soaking for 2 hours and then rinsed twice with sterile water. The imbibed seeds were aseptically
Strains of rhizobia corresponding to three indigenous and two exotic forage and pasture legumes were selected and recovered from both the frozen $\left(-70^{\circ} \mathrm{C}\right)$ and freeze dried cultures stored at the South African Rhizobium Culture Collection (SARCC). The strains from the frozen cultures were revived by streaking on Yeast Mannitol Agar (YMA) supplemented with Congo red [34], while cultures from the freeze dried ampoules were suspended using aliquots of sterile YM broth, streaked on YMA plates and incubated at $28^{\circ} \mathrm{C}$ for $5-8$ days. Single colonies were purified by sub-culturing on YMA plates. The purified single colonies were transferred into sterile YM broth and incubated at $28^{\circ} \mathrm{C}$ and $150 \mathrm{rpm}$ on a rotary shaker for 3 days. The concentration of the bacterial inoculum was adjusted to $10^{8} \mathrm{cfu} \mathrm{m}^{-1}$ using 0.5 McFarland standard [21] and the absorbance wavelength of $600 \mathrm{~nm}$.

\subsection{Glasshouse Plant Infection Test}

The indigenous forage legumes used in this study were Vigna unguiculata (L). Walp, Macrotyloma axillare var. axillare, and Indigofera spicata var. spicata while the two exotic legumes were Stylosanthus gracillis and Desmodium uncinatum. The list of the rhizobial strains used in this study and their initial legume host from which they were isolated is indicated in Table 1. 
the un-inoculated control, there were three replications arranged in a completely randomized design (CRD). The plants were harvested 60 days after planting inoculation. The data for shoot and root dry weight and nodule number were analyzed by means of analysis of variance (ANOVA) (SAS-9.1 software, SAS Institute, 2003). The means were compared by the General linear model (GLM) procedure and the least significance difference test (LSD) $)_{\mathrm{t}}$ at $p=$ 0.05 using SAS-9.1 software [27].

\subsection{Cultural and Physiological Characterization of Rhizobial Isolates}

The rhizobia were grown on YMA containing 0.5\% bromothymol blue (YMA-BTB) to detect acid or alkaline production by observing color change of the YMA plate after 3 days. To evaluate growth at various $\mathrm{pH}$ levels, the isolates were grown on Keyser defined medium [13) adjusted to different $\mathrm{pH}$ levels $(\mathrm{pH}=5,6.8,9)$. The plates were incubated at $28^{\circ} \mathrm{C}$ for 3-10 days and were examined for any growth. Temperature sensitivity of the isolates was detected by incubating the plates at temperatures $15^{\circ} \mathrm{C}$, $28^{\circ} \mathrm{C}$ and $36^{\circ} \mathrm{C}$. Intrinsic antibiotic resistance of the strains was conducted by studying their growth pattern on YMA media containing different concentrations of the antibiotics streptomycin, ampicillin and spectinomycin as described in [19].

\subsection{Characterization by 16S rRNA Nucleotide Sequencing}

Morphologically distinct colonies were grown on YMA medium and purified. The purified cultures were grown in Tryptone Yeast Extract (TY) broth for 24-48 hours at $28^{\circ} \mathrm{C}$, and $150 \mathrm{rpm}$ on a shaker. Isolation of genomic DNA was conducted using WIZARD ${ }^{\circledR}$ Genomic DNA Purification Kit according to the manufactures' instructions (Promega, Madison, USA). For the PCR reaction, universal primers fD1 (5'AGA GTT TGA TCC

TGG CTC AG-3) and rD1 (5’AAG GAG GTG ATC CAG CC3') corresponding to positions 8-27 and 1524 1540 respectively of $E$. coli $16 \mathrm{~S}$ rRNA were used [37]. PCR amplification reaction was performed in a $50 \mu \mathrm{l}$ volume containing: $10 \mu \mathrm{l}$ Go Taq flexi buffer, $1.5 \mathrm{mM}$ $\mathrm{MgCl}_{2}, 200 \mu \mathrm{M}$ dNTP each, $1.25 \mathrm{U}$ Go Taq DNA polymerase, $0.8 \mu \mathrm{M}$ each of the forward and reverse primers and $0.5 \mu \mathrm{g}$ of template DNA.

Amplifications were carried out in an Eppendorf Master cycler Gradient apparatus (Applied Biosystems, USA) using the following program [14]: an initial denaturation at $95^{\circ} \mathrm{C}$ for 3 min followed by 35 cycles of denaturation at $94^{\circ} \mathrm{C}$ for $1 \mathrm{~min}$, annealing at $55^{\circ} \mathrm{C}$ for $1 \mathrm{~min}$, extension at $72^{\circ} \mathrm{C}$ for 2 min and a final extension at $72^{\circ} \mathrm{C}$ for $3 \mathrm{~min}$. PCR amplified products were visualized by electrophoresis on a $1 \%$ agarose gel in TBE buffer containing $0.5 \mathrm{mg} / \mathrm{ml}$ ethidium bromide. Sequencing of the 16S PCR products was performed at Inqaba Biotech. (Pretoria, South Africa) and the resulting sequences were blast searched on the NCBI data library (http://blast.ncbi.nlm.nih.gov/Blast.cgi) to establish the identity of the isolates. The sequences were edited on Bioedit and Chomas Lite programs and aligned using MAFFT version 6 (http://mafft.cbrc.jp/alignment/server/) on line program. After all gaps were treated by the pair wise deletion method, Neighbor joining (NJ) and Unweighed Pair wise Group (UPGMA) phylogenetic trees were constructed using the Jukes Cantor and Kimura 2 models respectively. Resampled data sets of 1000 bootstrap were used as confidence test and analysis was conducted using the Mega 5.2 program [31]. The 16S rRNA sequences of 16 rhizobial strains used in this study are deposited at the Genbank data base library with the following accession numbers: GenBank KF989463 KF899479.

\section{Results}

\subsection{Glasshouse Plant Infection Test}

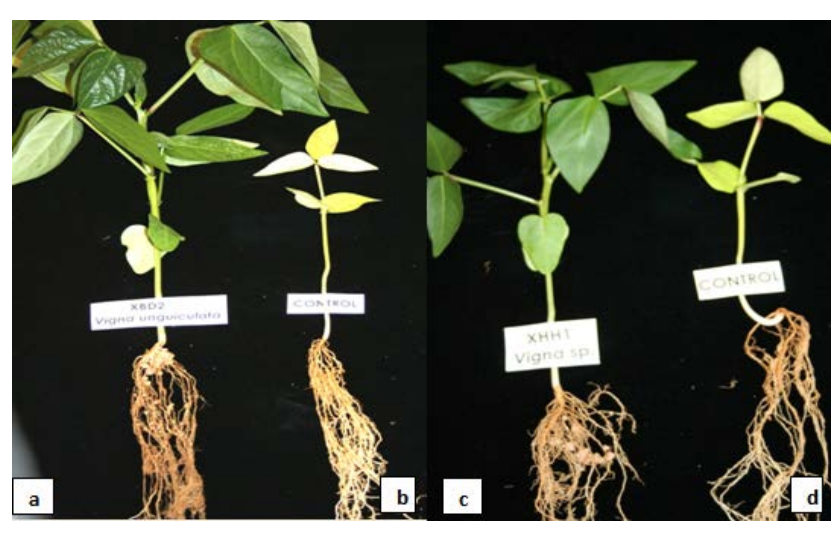

Figure 1. Inoculation of Vigna unguiculata with Bradyrhizobium strain $\mathrm{XBD} 2$, originally isolated from Cymopsis tetragoloba root nodule, resulted in several pink nodules (a) while un-inoculated plants are deficient in nitrogen and look yellow and are without nodules (b). Rhizobium strain XHH1 inoculation on Vigna sp. resulted in the formation of nodules by the roots with the leaves looking healthy and green (c) compared to the un-inoculated control (d).

All the rhizobia tested in the nodulation authentication trial in this study nodulated the indigenous and exotic forage legumes from which they were initially isolated. Some of the strains also resulted in the nodulation of a different host legume in addition to their original host. Nodulation test on Vigna unguiculata and Vigna sp. resulted in the formation of effective, pink nodules by all the tested strains with an average of $\geq 23$ nodules per plant. Of these, strain XBD2 formed 30 nodules per plant (Figure 1, Table 2) and also resulted in statistically significant increase $(p=0.05)$ in shoot dry weight. The highest number of nodules is formed by strains XFH12 and XFH1 (Table 2). Rhizobial strains which are microsymbionts of the forage legume Macrotyloma axillare also nodulated the legume with an average of 4-6 nodules per plant, very much lower compared to the micro- symbionts of Vigna sp. Except for strain XBV7, the remaining strains resulted in significant increase in shoot dry weight, but not in root dry weight (Table 3). Among the microsymbionts of Indigofera spp. tested in this study, strain SA59-2f resulted in a statistically significant increase $(p=0.05)$ in all the three parameters viz. shoot dry weight, nodule number and root dry weight. Strain SA59-2f formed an average of 23 nodules per plant (Table 4). Another statistically significant increase in all the three parameters was observed by strain XGA1, the microsymbionts of Desmodium uncinatum. Strain XBQ5, also nodulated the target legume and formed an average of 
18 nodules per plant (Table 5). The nodulation authentication test using strains XFH12 and XHG1 on the forage legume Stylosanthus gracillis did not result in statistically significant increase in any of the parameters tested due to the very less number of treatments used for reasons of seed unavailability. However both XFH12 (which also nodulated Vigna sp.) and XHG1 were able to nodulate Stylosanthus roots with the formation of 8 and 3 nodules per plant respectively (Table 6).

Table 2. Measurement of root and shoot biomass, and nodule number of Vigna sp. grown under glasshouse conditions and harvested 60 days after inoculation with various strains of rhizobia from the SARC collection

\begin{tabular}{cccc}
\hline \multirow{2}{*}{$\begin{array}{c}\text { Rhizobium } \\
\text { Isolates }\end{array}$} & $\begin{array}{c}\text { Plant Biomass } \\
\text { weight }(\mathrm{g})^{*}\end{array}$ & $\begin{array}{c}\text { Root Dry weight } \\
(\mathrm{g})^{*}\end{array}$ & $\begin{array}{c}\text { Nodule }^{*} \\
\text { Number }^{*}\end{array}$ \\
\cline { 2 - 4 } XBD2 & $4.9333^{\mathrm{a}^{*}}$ & $0.15667^{\mathrm{a}^{*}}$ & $30.667^{\mathrm{a}^{*}}$ \\
XFH12 & $0.5833^{\mathrm{b}}$ & $0.15667^{\mathrm{a}}$ & $35.333^{\mathrm{a}}$ \\
XFH3 & $0.8533^{\mathrm{b}}$ & $0.10333^{\mathrm{a}}$ & $30.667^{\mathrm{a}}$ \\
XHH1 & $0.3933^{\mathrm{b}}$ & $0.10333^{\mathrm{a}}$ & $23.667^{\mathrm{a}}$ \\
XFH1 & $0.7133^{\mathrm{b}}$ & $0.06000^{\mathrm{a}}$ & $35.333^{\mathrm{a}}$ \\
Control & $0.3900^{\mathrm{b}}$ & $0.06000^{\mathrm{a}}$ & $0.000^{\mathrm{b}}$ \\
\hline LSD $D_{0.05}$ & 0.9874 & 0.1134 & 13,226 \\
\hline Pr $>F$ & $<0.0001$ & $<0.2447$ & $<0.0011$ \\
\hline *Values are the means of three replications and means followed by \\
different letters are significantly different \\
according to the general Linear Model procedure of the Least \\
Significance Difference (LSD) test at P=0.05
\end{tabular}

Table 3. Measurement of root and shoot biomass, and nodule number of Macrotyloma axillare var. axillare grown under glasshouse conditions and harvested 60 days after inoculation with various strains of rhizobia

\begin{tabular}{cccc}
\hline \multirow{2}{*}{$\begin{array}{c}\text { Rhizobium } \\
\text { Isolates }\end{array}$} & \multicolumn{2}{c}{ Plant Biomass } & \\
\cline { 2 - 4 } & $\begin{array}{c}\text { Shoot Dry } \\
\text { weight }(\mathrm{g})^{*}\end{array}$ & $\begin{array}{c}\text { Root Dry } \\
\text { weight }(\mathrm{g})^{*}\end{array}$ & $\begin{array}{c}\text { Nodule } \\
\text { Number }^{*}\end{array}$ \\
\hline \hline XBV5 & $0.11700^{\mathrm{a}}$ & $0.02773^{\mathrm{a}}$ & $6.833^{\mathrm{a}}$ \\
XBU3 & $0.07933^{\mathrm{a}}$ & $0.02000^{\mathrm{a}}$ & $6.833^{\mathrm{a}}$ \\
XBU4 & $012833^{\mathrm{a}}$ & $0.13200^{\mathrm{a}}$ & $6.000^{\mathrm{a}}$ \\
XBV7 & $0.02813^{\mathrm{b}}$ & $0.00987^{\mathrm{a}}$ & $5.167^{\mathrm{a}}$ \\
XBT2 & $0.08833^{\mathrm{a}}$ & $0.03013^{\mathrm{a}}$ & $4.333^{\mathrm{a}}$ \\
Control & $0.02650^{\mathrm{b}}$ & $0.01567^{\mathrm{a}}$ & $0.000^{\mathrm{b}}$ \\
\hline LSD & 0.0506 & 0.1325 & 3.7566 \\
\hline Pr $>\mathrm{F}$ & $<0.0042$ & $<0.3756$ & $<0.0187$ \\
\hline
\end{tabular}

*Values are the means of three replications and means followed by different letters are significantly different according to the general Linear Model procedure of the Least Significance Difference (LSD) test at $P=0.05$

Table 4. Measurement of root and shoot biomass, and nodule number of Indigofera spicata var.spicata grown under glasshouse conditions and harvested 60 days after inoculation with various strains of rhizobia

\begin{tabular}{cccc}
\hline $\begin{array}{c}\text { Rhizobium } \\
\text { isolates }\end{array}$ & \multicolumn{2}{c}{ Plant biomass } & \\
\cline { 2 - 4 } & $\begin{array}{c}\text { Shoot Dry } \\
\text { Weight (g)* }\end{array}$ & $\begin{array}{c}\text { Root Dry } \\
\text { Weight }(\mathrm{g})^{*}\end{array}$ & $\begin{array}{c}\text { Nodule } \\
\text { Number* }^{*}\end{array}$ \\
\hline \hline SA59-2f & $0.4698^{\mathrm{a}^{*}}$ & $0.1760^{\mathrm{a}^{*}}$ & $23.850^{\mathrm{a}^{*}}$ \\
SA59-2c & $0.2309^{\mathrm{b}}$ & $0.0467^{\mathrm{b}}$ & $10.500^{\mathrm{c}}$ \\
XCG2 & $0.1156^{\mathrm{bc}}$ & $0.0311^{\mathrm{b}}$ & $12.167^{\mathrm{b}}$ \\
XGO1 & $0.1550^{\mathrm{bc}}$ & $0.0332^{\mathrm{b}}$ & $10.500^{\mathrm{c}}$ \\
SA59-2e & $0.0870^{\mathrm{bc}}$ & $0.0288^{\mathrm{b}}$ & $8.667^{\mathrm{cd}}$ \\
Control & $0.0244^{\mathrm{c}}$ & $0.0153^{\mathrm{b}}$ & $0.0000^{\mathrm{d}}$ \\
\hline LSD & 0.1497 & 0.0994 & 11.458 \\
\hline Pr>F & $<0.0007$ & $<0.0397$ & $<0.0093$ \\
\hline
\end{tabular}

$*$ Values are the means of three replications and means followed by different letters are significantly different according to the general Linear Model procedure of the Least Significance Difference (LSD) test at $P=0.05$
Table 5. Measurement of root and shoot biomass, and nodule number of Desmodium uncinatum grown under glasshouse conditions and harvested 60 days after inoculation with various strains of rhizobia

\begin{tabular}{cccc}
\hline \multirow{2}{*}{$\begin{array}{c}\text { Rhizobium } \\
\text { Isolates }\end{array}$} & \multicolumn{2}{c}{\begin{tabular}{c} 
Plant Biomass \\
\cline { 2 - 4 }
\end{tabular}} & \multicolumn{2}{c}{$\begin{array}{c}\text { Shoot Dry Weight }(\mathrm{g})^{*} \text { Root Dry } \\
\text { Weight }(\mathrm{g})^{*}\end{array}$} & $\begin{array}{c}\text { Nodule } \\
\text { Number* }^{*}\end{array}$ \\
\hline \hline XBQ5 & $0.0303^{\mathrm{b}}$ & $0.01967^{\mathrm{b}}$ & $18.333^{\mathrm{a}}$ \\
XGA1 & $0.9913^{\mathrm{a}}$ & $0.50300^{\mathrm{a}}$ & $17.467^{\mathrm{a}}$ \\
XGE1 & $0.0213^{\mathrm{b}}$ & $0.03800^{\mathrm{b}}$ & $12.333^{\mathrm{ab}}$ \\
Control & $0.0363^{\mathrm{b}}$ & $0.04567^{\mathrm{b}}$ & $0.000 \mathrm{~b}$ \\
\hline LSD $_{0.05}$ & 0.2791 & 0.1213 & 17.122 \\
\hline Pr>F & $<0.0003$ & $<0.0005$ & $<0.2217$ \\
\hline
\end{tabular}

$*$ Values are the means of three replications and means followed by different letters are significantly different according to the general Linear Model procedure of the Least Significance Difference (LSD) test at $\mathrm{P}=0.05$

Table 6. Measurement of root and shoot biomass, and nodule number of Stylosanthus gracillis grown under glasshouse conditions and harvested 60 days after inoculation with various strains of rhizobia

\begin{tabular}{cccc}
\hline \multirow{2}{*}{$\begin{array}{c}\text { Rhizobium } \\
\text { Isolates }\end{array}$} & \multicolumn{3}{c}{ Plant biomass } \\
\cline { 2 - 4 } & $\begin{array}{c}\text { Shoot Dry weight } \\
(\mathrm{g})^{*}\end{array}$ & $\begin{array}{c}\text { Root Dry weight } \\
(\mathrm{g})\end{array}$ & $\begin{array}{c}\text { Nodule } \\
\text { number }^{*}\end{array}$ \\
\hline \hline XHF12 & $0.06467^{\mathrm{a}}$ & $0.009667^{\mathrm{a}}$ & $8.776^{\mathrm{a}}$ \\
XHG1 & $0.04733^{\mathrm{a}}$ & $0.00800^{\mathrm{a}}$ & $3.223^{\mathrm{a}}$ \\
$\mathrm{CONTROL}^{\mathrm{a}}$ & $0.02667^{\mathrm{a}}$ & $0.012667^{\mathrm{a}}$ & $0.000^{\mathrm{a}}$ \\
\hline $\mathrm{LSD}_{0.05}$ & 0.0471 & 0.0076 & 43.493 \\
\hline $\mathrm{Pr}>\mathrm{F}$ & $<0.1962$ & $<0.5739$ & 0.3921
\end{tabular}

*Values are the means of three replications and means followed by different letters are significantly different according to the general Linear Model procedure of the Least Significance Difference (LSD) test at $\mathrm{P}=0.05$

\subsection{Cultural and Physiological Characteristics}

The average colony size among the strains ranges from $0.2 \mathrm{~mm}-2.8 \mathrm{~mm}$ in diameter with various colony morphologies. Many of the strains were characterized by the production of extracellular gum production with characteristic elastic colony formation on the YMA solid media. Others which do not produce extracellular gum exhibit somewhat a buttery colony. The fast growing strains (XFH1 and XHH1) identified as Sinorhizobium sp. and Rhizobium sp. respectively produced acid on YMA$\mathrm{BTB}$ and grew well both at the optimum $\mathrm{pH}$ and $\mathrm{pH}=5$. They were also found to be tolerant to a temperature of $37^{\circ} \mathrm{C}$ (Data not shown). While all the other strains with the highest similarity with members of the genus Bradyrhizobium produced an alkaline reaction and showed optimum growth at $\mathrm{pH} 6.8$ and 9. The slow growing Bradyrhizobium strains XBD2, XFH12, XFH3, SA59-2c, SA59-2e and SA59-2 were tolerant to a temperature as high as $37^{\circ} \mathrm{C}$ (Data not shown).

\subsection{S rRNA PCR Amplification and Sequencing Analysis}

Consensus sequences of $\geq 1350$ bp amplification products of the 16S rRNA regions were used to construct Neighbor Joining (NJ) and Un-weighed Pair wise Group (UPGMA) phylogenetic trees. Both the NJ and UPGMA methods provided phylogenetic trees of similar topology. For the sake of convenience, we categorized the groups in the tree into seven major clusters. Except two isolates nodulating Vigna sp., all the other isolates tested in the glasshouse trial clustered under four major groups of the 
Bradyrhizobium lineage. The first cluster in the NJ tree (cluster IV in UPGMA) contained strain XBD2, a potentially effective nitrogen fixing and highly competitive strain initially isolated from Cyamopsis tetragonoloba. When tested on Vigna unguiculata (a cowpea cross inoculation group), it formed very effective nodules in terms of nodule color, size and position. In both trees XBD2 clustered with Bradyrhizobium canariense CCBAU 51257 and Bradyrhizobium sp. ORS 3651 with a high bootstrap support (Figure 2 and Figure 3 ). The second big cluster contains strains which are the symbionts of Indigofera spicata var. spicata, Macrotyloma axillare and V. unguiculata. The strains are XCG2, SA59-2f, XBV7, XFH12, XFH3 and XFH14 which clustered with different strains of $B$. japonicum at a bootstrap level between 58-98\%. Although XFH14 forms a cluster with a strain of $B$. japonicum in the NJ tree, it only has a $91 \% 16 \mathrm{~S}$ rRNA similarity with strains from the NCBI database. In the UPGMA tree, this is clearly reflected as the strain does not cluster with any group (Figure 2 and Figure 3). All the remaining isolates had a 16S rRNA similarity of $99 \%$ with $B$. japonicum strains (Table 1). The third cluster (cluster II, UPGMA) contains only one strain, SA59-2e which falls under the group which contains Bradyrhizobium genospecies and Bradyrhizobium species. In cluster IV of the NJ tree, strains SA59-2c, XGOI and XBU4 formed their own cluster within the Bradyrhizobium lineage, but not associating with any of the reference Bradyrhizobium strains used. All three strains three had a 16S rRNA similarity of only $91-98 \%$ with $B$. elkani reference strains.

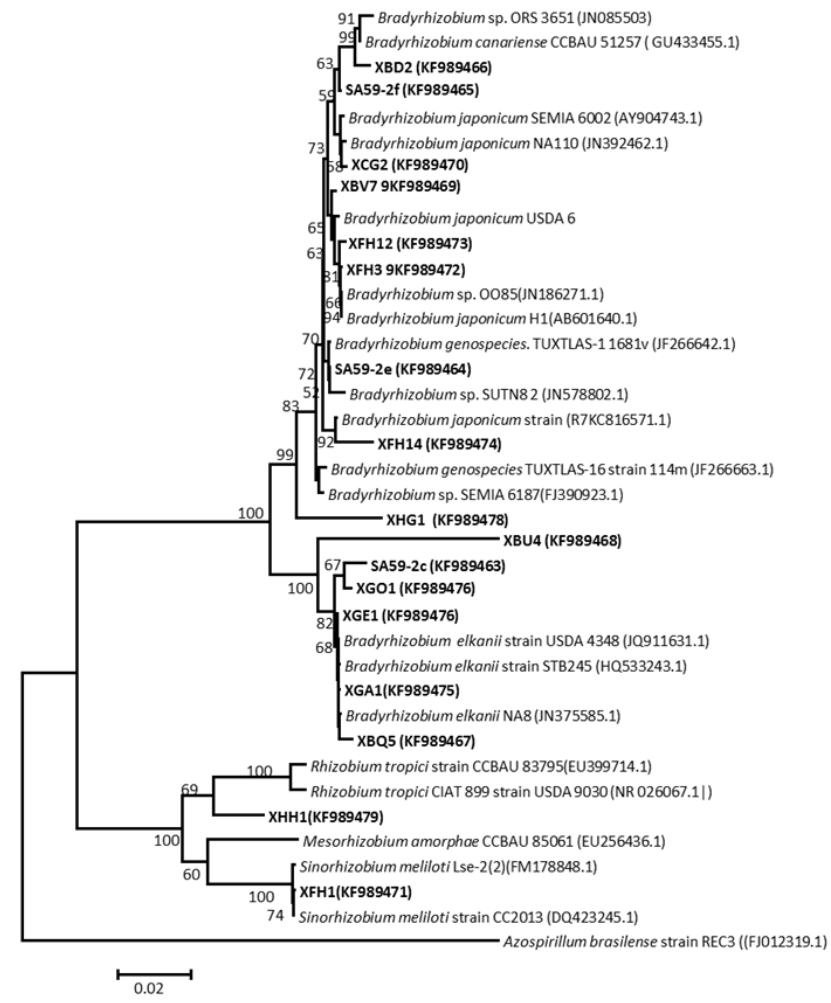

Figure 2. Neighbour Joining (NJ) tree showing the phylogenetic relatedness of $16 \mathrm{~S}$ rRNA sequences for 17 rhizobia associated with the nodulation of indigenous and exotic forage legumes and 22 reference sequences obtained from GenBank data base. Bootstrap support based on analysis of 1000 resampled data sets in which only values $>50 \%$ are indicated. The evolutionary distances were computed using the JukesCantor method. Scale bar represents 2 substitutions per 100 nucleotide positions. The tree is rooted with Azosprillum brasilense REC3

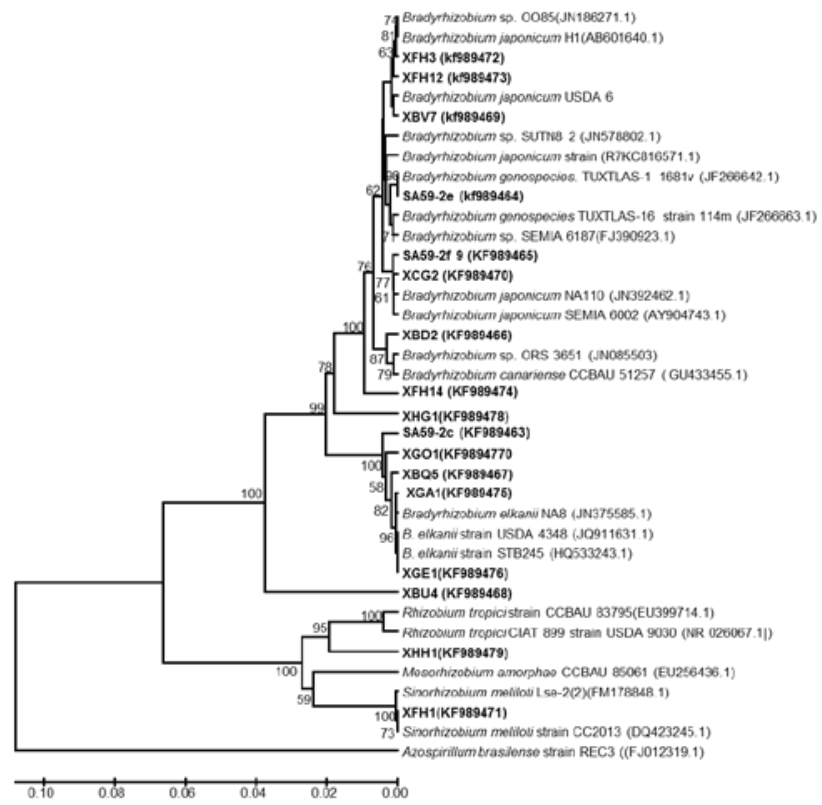

Figure 3. Unweighted Pair Group (UPGMA) phylogenetic tree of 17 rhizobia associated with the nodulation of indigenous and exotic forage legumes and 22 reference sequences obtained from the GenBank based on 16S rRNA sequences analysis. Bootstrap support ( $>50 \%)$ based on analysis of 1000 resampled values are indicated. The evolutionary distances were computed using the Kimura 2-parameter method. Scale bar represents 2 substitutions per 100 nucleotide positions. The tree is rooted with Azosprillum brasilense REC3.

Strains XGA1 and XBQ5 which nodulated Desmodium uncinatum and strain XGE1 which nodulated Indigofera spicata var. spicata all clustered with the B. elkani group at a very high bootstrap level in both the NJ and UPGMA trees (cluster $\mathrm{V}$ ). At the bottom of both the $\mathrm{NJ}$ and UPGMA trees, we find strains XHH1 and XFH1 both of which are the symbionts of $V$. unguiculata and formed separate clusters with members of the genus Rhizobium and Sinorhizobium respectively. The $16 \mathrm{~S}$ rRNA similarity for XHH1 was 99\% with Rhizobium sp. UMR7363 and that of XFH1 was 99\% with Sinorhizobium meliloti MB12 and the tree branches for both strains were supported by a high bootstrap level.

\section{Discussion}

A large collection of Rhizobia isolated from the root nodules of various legumes and preserved at the South African Rhizobium Culture Collection (SARCC) in the past have not been studied in detail. In this study, rhizobial strains associated with the nodulation and nitrogen fixation of selected forage legumes including Macrotyloma axillare var. axillare, Desmodium uncinatum, Indigofera spicata var. spicata, Stylosanthes gracillis, and Vigna unguiculata were characterized. Based on the 16S rRNA sequence analysis, the strains tested for nodulation of these indigenous and exotic forage legumes fall under four major different phylogenetic groups mainly under the Bradyrhizobium japonicum and Bradyrhizobium elkani lineages. Two of these strains isolated from Vigna unguiculata formed a separate cluster with the Sinorhizobium and Rhizobium lineages.

Cowpea [Vigna unguiculata (L.) Walp] is not only used as an important source of protein in low income population of most developing countries [28], but can also 
serve as a valuable forage and green manure crop. In China for instance cowpea is a valuable forage and green manure crop for the stock breeding and the improvement of soil fertility $[16,40]$. The cowpea rhizobia have long been grouped into the cowpea cross inoculation group generally containing members of the genus Bradyrhizobium [26]. A cross inoculation group consists of a collection of legume species that will develop effective nodules when inoculated with the rhizobia obtained from the nodules of any member of that legume group [29].

In the current glasshouse nodulation study, strain XBD2 which was initially isolated from Cyamopsis tetragonoloba effectively nodulated $V$. unguiculata. The strain was also found to belong to Bradyrhizobium sp. with a strong similarity in its $16 \mathrm{~S}$ rRNA supporting the cowpea cross inoculation group concept. However, two other isolates viz. XFH1 and XHH1 which were initially isolated from $V$. unguiculata belonged to Sinorhizobium sp. and Rhizobium sp. respectively both with a $99 \%$ similarity in their 16S rRNA. Rhizobia from the Sinorhizobium and Rhizobium genera are not so common in the cowpea cross inoculation group. The detection of these two isolates from the root nodules of Vigna sp. in this study is in accordance with a previous work which revealed the occurrence of fast growing Sinorhizobium fredi and Rhizobium leguminosarum in the nodules of $V$. unguiculata [39]. In a recent study of nitrogen fixing bacterial population under agroforestry system [11], $V$. unguiculata was found to nodulate with a high diversity of rhizobia although $70 \%$ of these belong to the genus Bradyrhizobium. Furthermore, the nodulation of Stylosanthus gracillis in this study by stain XFH12, microsymbionts of $V$. unguiculata could be an indication that Bradyrhizobium strains from cowpea cross inoculation group exhibit complicated host nodulation capacity. For instance earlier studies indicated that Vigna strains belonging to members of the genus Bradyrhizobium have been observed to nodulate on promiscuous tropical and subtropical legumes from other species not grouped in the cowpea cross inoculation group such as Phaseolus lunatus and Macroptilium atropurpureum [32,33].

Strain XBQ5 initially isolated from Desmodium uncinatum and strain XGAI which was isolated from Desmodium nacaraguene were both able to nodulate $D$. uncinatum in this study. This tropical pasture legume which is used as ground cover is also involved in improving soil fertility. Both XBQ5 and XGA1 have shown a 99\% similarity with Bradyrhizobium elkani SEMIA and USDA strains and also clustered with these type strains in the phylogenetic analysis. The result is in agreement with [22] who analyzed the 16S rRNA sequences of nodule strains of Desmodium uncinatum from three different geographical locations including Australia, Zimbabwe and Colombia and who found that all the strains belonged to $B$. elkani. Although it is generally believed that these tropical pasture legumes are nodulated by Bradyrhizobium sp. [7], the results in this study and the previous finding [22] suggest that the microbial symbionts associated with the nodulation of Desmodium uncinatum and Desmodium species mainly fall within the B. elkani lineage.
The 16S rRNA sequence similarities for strain XFH14, a symbiont of $V$. unguiculata and strain XHG1, a symbiont of Stylosanthus gracillis was as extremely low as $91 \%$ and $95 \%$ respectively. Another strain which effectively nodulated Macrotyloma axillare, formerly known as Dolichos axillare, was only related in its $16 \mathrm{~S}$ nucleotide sequence to B. elkani CCBAU 33018 at $91 \%$ which can be used to infer that these strains belong to a different Bradyrhizobium species [6]. Moreover, in both method of analysis used in this study, these three strains formed a substantial branch length compared to all the Bradyrhizobium lineages indicating they belong to a new Bradyrhizobium species. Further studies including analysis of housekeeping and symbiotic genes could reveal the exact species identity of these strains in the Bradyrhizobium lineage.

As shown in Table 2 in this study, some of the rhizobial strains are able to nodulate more than one plant genus showing the promiscuous nature of the strains. The strains which were initially isolated from the nodules of Indigofera hirusta in the current study all nodulated a related forage legume of different genus, Indigofera spicata var. spicata. In the phylogenetic grouping, the strains fall under the Bradyrhizobium lineage but distributed across the separate clades containing $B$. japonicum (strains XCG2, SA59-2f). B. elkani (XGE1, XGO1, SA59-2c) and Bradyrhizobium spp.(SA59-2e). This probably indicates that forage legumes belonging to Indigofera spp. may be nodulated by a wide range of Rhizobium species even by strains outside of the Bradyrhizobium lineage. An excellent example could be the nodulation of Indigofera tinctoria by bacteria related to five different generic group including Rhizobium, Bradyrhizobium and Sinorhizobium spp. [17]. In earlier studies on the genetic diversity of root nodule bacteria from Indigofera tinctoria and Indigofera sp., the fast growing Rhizobium and Sinorhizobium spp. were found to be associated with the root nodules of this legume [25,35].

Other strains of rhizobia in this study that exhibited promiscuity, nodulating more than one genus of legume include XBD2, the microsymbiont of Cyamopsis tetragonoloba but which also nodulates Vigna unguiculata, XFH12 which nodulates both $V$. unguiculata and Stylosanthus gracillis and strain XGA1 which nodulates Desmodium uncinatum and $D$. nacaraguence. This result concurs with earlier reports that rhizobia of herbaceous host species are more promiscuous than those of woody legumes [36]. On the other hand, the occurrence of rhizobia belonging to different genera in the same host could be explained in terms of the genetic diversification and adaptation of the rhizobia to their environment [5].

In conclusion, although the data presented in this study revealed that the microsymbionts associated with the nodulation of forage and pasture legumes mainly belong to members of the genus Bradyrhizobium, strains of Rhizobium and Sinorhizobium spp. were also found to nodulate these legumes. For a greater understanding of the symbiotic interaction of the wide range of indigenous and exotic forage legumes on South African soils, the study warrants further research using the polyphasic approach, which involves genetic analysis of various housekeeping and symbiotic genes of the rhizobial strain. 


\section{Acknowledgement}

The authors would like to acknowledge Dr Marike Trytsman of the ARC-Animal Production Institute, in addition to co-authoring this manuscript, for partially funding this project and for making available the seeds of exotic and indigenous legumes used in the glasshouse test. Due acknowledgement also goes to the ARC-Plant Protection Research Institute for the partial funding of this work.

\section{References}

[1] Anonymous, "First step to reduce plant need for nitrogen fertilizer uncovered”, Science Daily, September 2013. [Online]. Available: http:

//www.sciencedaily.com/releases/2013/09/130927183314.htm/. [Accessed Apr 3, 2014].

[2] Bloem, J.F., Trytsman, G., Smith, H.J, "Biological nitrogen fixation in resource poor agriculture in South Africa”, Symbiosis, 48: 18-24. 2009.

[3] De Lajudie, P., Laurent-Fulele, E., Willems, A., Torck, U., Coopman, R., Collins, M.D., Kersters, K., Dreyfus, B., Gills, M, "Allorhizobium undicola gen. nov., nitrogen fixing bacteria that efficiently nodulates Neptunia natans in Senegal”, Int J Syst Bacteriol, 48: 1277-1290. 1998.

[4] Diognon-Bourcier, F., Willems, A., Coopman, R., Laguerre, G., Gills, M., De Lajudie, P., "Genotypic Characterization of Bradyrhizobium Strains Nodulating Small Senegalese Legumes by 16S-23S rRNA Intergenic Gene Spacers and Amplified Fragment Length Polymorphism Fingerprint Analyses”, Appl Environ Microbiol, 66: 3987-3997. 2000.

[5] Fuentes, J.B., Abe, M., Uchiumi, T., Suzuki, A., Higashi, S., "Symbiotic root nodule bacteria isolated from yam bean (Pachyrhizus erosus)”, J Gen Appl Microbiol, 48: 181-191. 2002.

[6] Garau, G., Yates, R. J., Deiana, P., Howeison J.G., "Novel strains of nodulating Burkholderia have a role in nitrogen fixation with papilionoid herbaceous legumes adapted to acid infertile soils”, Soil Biol Biochem. 41: 125-134. 2009.

[7] Giller, K.E., Wilson, K.J, "Nitrogen fixation in tropical systems", CAB International, Redwood Press Ltd. UK, Melksham, Wiltshire, 1991, 136-153.

[8] Gyaneshwar, P., Hirsh, A.M., Moulin, L., Chen, W.M., Elliot, G.N., Bontemps, C., Estrada de-los Santos, P., Gross, E., Bueno dos Reis, F. Jr., Sprent, J., Young, J.P.W., James, E.K., "Legume nodulating beta-Proteobacteria: diversity, host range and future prospects”, Mol Plant Microbe Interac, 24: 1276-1288. 2011.

[9] Howieson, J. G., “The host-rhizobia relationship. In: Beneth SJ, Cook PS (eds.) Genetic Resources of Mediterranean Pasture and Forage Legumes”, Kluwer Academic Publisher, Netherlands, 1999, 96-106.

[10] Howieson, J.G., Yates, R.J., Foster, K.J., Real, D., Besiel, R.D., In: Dilworth MJ, James EK., Sprent JI, Newton WE (eds.) Prospects for future use of legumes., Springer, Dordrecht, Netherlands, 2008, 363-393.

[11] Jaramillo, P.M.D., Guimaraes, A.Z., Florentino, L.A., Silva, K. B., Noberga, R.S.A., de Souza Moreira, F., "Symbiotic nitrogen fixing bacterial populations trapped under agroforestry systems in the Western Amazone”, Scientia Agricola, 70: 397-404. 2013.

[12] Kala, T.C., Christi, R. M., Bai, R. N, 'Effect of rhizobium inoculation on the growth and yield of Horse gram (Dolichos biflorus linn)”, Plant Archives, 11: 97-99. 2011.

[13] Keyser, H.M., Munns. D.N., "Tolerance of rhizobia to acidity aluminium and phosphate”, Soil Sci Soc Am J, 43: 519-523. 2011.

[14] Laguerre, G., Allard, M.R., Revoy, F., Amarger, N., "Rapid identification of rhizobia by restriction fragment length polymorphism analysis of PCR-amplified 16S rRNA genes”, Appl Environ Microbiol, 60: 56-63.1994.

[15] Laguerre, G, Nour, S.M., Macheret, V., Sanjuan, J., Droiun, P., Amarger, N., "Classification of rhizobia based on nodC and nifH gene analysis reveals a close phylogenetics relationship among Phaseolus vulgaris symbionts”, Microbiol, 147: 981-993. 2001.

[16] Law, I.J., Botha, W.J., Majaule, U.C., Phalane, F.L., "Symbiotic and genomic diversity of "cowpea" bradyrhizobia from soils in Botswana and South Africa”, Biol Fertil Soils, 43: 653-663, 2007.
[17] Leelahawonge, C., Nuntagig, A., Teaumroong, N., Boonkerd, N. Pongslip, N., "Characterization of root nodule bacteria isolated from the medicinal legume Indigofera tinctoria” Ann Microbiol, 60: 65-74. 2010.

[18] Lindstrom, K.., Murwira, M., Willems, A., Altier, N., "The biodiversity of beneficial microbe-host mutualism: the case of rhizobia”, Res in Microbiol, 161: 453-463. 2010.

[19] Lupwayi, N.Z., Haque, I., "Legume Rhizobium Technology Manual”, No. 19, International Livestock Centre for Africa, Addis Ababa, Ethiopia, 1994, 27-28.

[20] Lupwayi, N.Z., Kennedy, A.C., Chirwa, R.M., "Grain legume impacts on soil biological processes in Sub-Saharan Africa”, African J. Plant Sci, 5: 1-7. 2011.

[21] McFarland, J, “The nephilometer: An instrument for estimating the number of bacterial suspensions used in calculating the opsonic index of vaccines”, J Am Med Asso, 49: 1176-1178. 1907.

[22] Menna, P., Hungaria, M., Barcellos, F.G., Bangel, E.V., Hess, P.N., Martinez-Romero, E., "Molecular phylogeny based on the 16S rRNA gene of elite rhizobial strains used in Brazillian commercial inoculants”, Syst Appl Microbiol, 29: 315-332. 2006.

[23] O’Hara, G., Yates, R., Howieson, J., "Selection of strains of root nodule bacteria to improve inoculants performance and increase legume productivity in stressful environments”. In: D. Herridge (ed.) Inoculants and nitrogen fixation of legumes in Vietnam, 2002.

[24] Peoples, M.B., Craswell, E.T., "Biological nitrogen fixation: Investments, expectations and actual contribution to agriculture", Plant Soil, 141: 13-39. 1992.

[25] Pongslip, N., Nuntagij, A., "Genetic diversity and metabolites production of root nodule bacteria isolated from medicinal legumes of Indigofera tinctoria, Pueraria mirifica and Derris elliptica Benth. grown in different geographical origins across Thailand”, American Eurasian J Agric Environ Sci, 6: 26-34. 2009.

[26] Sarr, P.S., Yamakawa, T., Fujimuto, S., Saeki, Y., Thao, H.T.B., Myint, K., Phylogenetic diversity and symbiotic effectiveness of root nodule bacteria associated with cowpea in South West area of Japan. Microbes Environ, 24: 105-112. 2009.

[27] SAS Institute, "SAS/STAT guide for personal computers", SAS Institute, Cary, 2003.

[28] Singh, B.B., Mohan Raj, D. R., Dashiel, K.E., Jackie, L., "Advances in cowpea research", ITTA-JIRCAS, Ibadan, Nigeria, 1997.

[29] Somasegaran, P., Hoben, H.J., "Hand book for rhizobia: Methods in Legume-Rhizobium Technology," Springer-Verlag, New York, 1994.

[30] Strijdom, B.W., "South African studies on biological nitrogen fixing systems and the exploitation of the nodule bacterium legume symbiosis”, S Afr J Sci, 94: 11-23. 1998.

[31] Tamura, K., Dudley, J., Nei M, Kumar, S., "MEGA 4: Molecular Evolutionary Genetics Analysis (MEGA) software version 4.0", Mol Biol Evol, 24: 1596-1599. 2007.

[32] Thies, J. E., Bohlool, B. B., Singleton, P. W., "Subgroups of cow pea miscellany: symbiotic specificity within Bradyrhizobium spp. for Vigna unguiculata, Phaseolus lunatus, Arachis hypogeal, and Macroptillium artropurpureum, Appl Environ Microbiol, 57: 1540-1545. 1991.

[33] Trinick, M. J., Hadobas, P. A., "Effectiveness and competition for nodulation of Vigna unguiculata and Macroptillium atropurpureum with Bradyrhizobium spp. from Parasponia”, Can J Microbiol, 35: 1156-1163. 1989.

[34] Vincent, J. M., "A manual for the practical study of root nodule bacteria” In: International Biological Programme Handbook No. 15, Blackwell Scientific Publications Ltd, Oxford, 1970. 73-97.

[35] Wei, G. H., Wang, E. T., Tan, Z. Y., Zhu, M. E., Chen, W. X., "Rhizobium indigoferae sp. nov. and Sinorhizobium kummerowiae sp. nov., respectively isolated from Indigofera spp. and Kummerowia stipulacea”, Int J Syst And Evol Microbiol, 52: 2231-2239, 2002.

[36] Weir, B.S., Turner, S.J., Silvester, W. B., Park D-C., Young, J. M., "Unexpectedly diverse Mesorhizobium strains and Rhizobium leguminosarum nodulate native legume genera of NewZealand while introduced legume weeds are nodulated by Bradyrhizobium species”, Appl Environ Microbiol 70: 5980-5987. 2004.

[37] Weisburg, W.G., Barns, S.M., Pelletier, D.A., Lane, D. J., “16S Ribosomal DNA Amplification for Phylogenetic study”, $J$ Bacteriol, 173: 697-703. 1991.

[38] Young, J.P.W., Haukka, K. "Diversity and phylogeny of rhizobia”, New Phytol, 133: 87-94. 1996.

[39] Zhang, W.T., Yang, J.K., Yuan, T. Y., Zhou, C. J., "Genetic diversity and phylogeny of indigenous rhizobia from cowpea 
[Vigna unguiculata (L.) Walp]”, Biol Fert Soils, 44: 201-210. 2007.

[40] Zilli, J. E., Valisheski, R. R., Filho, F. R. F., Neves, M. P. C. Rumjanek, N. G., "Assessment of cowpea rhizobium diversity in
Cerrado areas of Northeast Brazil”, Brazil J Microbiol, 35: 281287, 2004. 